\title{
VITAMIN D3 ALLEVIATES CALCIUM AND PHOSPHORUS DEFICIENCY IN BROILERS
}

\author{
M.A.M. Abdelaziz; N.M. El-Medany; A.A. Hemid and H.A. El-Alaily \\ Poultry Science Department, Ain Shams University, Cairo, 11241, Egypt.
}

\section{SUMMARY}

\begin{abstract}
$\mathrm{A}$ n experiment was carried out to examine effects of using extra dietary vitamin D3 along with low levels of calcium $(\mathrm{Ca})$ and phosphorus $(\mathrm{P})$ on performance, bone quality and mineral retention of broilers. Three starter diets were used; Control (C), Medium (M) and Low (L) which contain Ca: $1.00,0.75$ and $0.50 \%$; non-phytate P (NPP): $0.50,0.37$ and $0.25 \%$; D3: 3,000, 5,000 and 7,000 IU/kg, respectively. As well, three grower diets were used; (C), (M) and (L) contain Ca: 0.90, 0.65, and 0.40\%; NPP: $0.45,0.32$ and $0.20 \%$; D3: 3,000, 6,000 and 9,000 IU/kg, respectively. Six treatment groups were distributed according to diets fed in starter and grower periods consecutively; $(\mathrm{C} / \mathrm{C}),(\mathrm{C} / \mathrm{M}),(\mathrm{C} / \mathrm{L}),(\mathrm{M} / \mathrm{M}),(\mathrm{M} / \mathrm{L})$ and $(\mathrm{L} / \mathrm{L})$. Each group contained 40 birds in four replicates 10 chicks each. Body weight gain, feed efficiency, plasma concentration of $\mathrm{Ca}$ and $\mathrm{P}$ and plasma alkaline phosphatase activity, were not affected by dietary treatments compared to $(\mathrm{C} / \mathrm{C})$ except for $(\mathrm{C} / \mathrm{L})$ group. Similarly, tibia breaking strength, tibia ash and $\mathrm{Ca}$ and $\mathrm{P}$ percentage, were not affected by different dietary treatments except for $(\mathrm{C} / \mathrm{L})$ group which recorded lower bone density compared to $(\mathrm{C} / \mathrm{C})$ group. Birds of $(\mathrm{C} / \mathrm{L}),(\mathrm{M} / \mathrm{L})$ or $(\mathrm{L} / \mathrm{L})$ groups retained more $\mathrm{Ca}$ and $\mathrm{P}$ compared with those of other treatments. Based on results obtained, it could be concluded that extra vitamin D3 supplementations $(9,000 \mathrm{IU} / \mathrm{Kg})$ to low $\mathrm{Ca}$ and NPP $(0.40$ and $0.20 \%$, respectively) diets could alleviate performance, bone quality and mineral retention, and decrease environmental pollution especially with $\mathrm{P}$, as well as to minimize feed cost.
\end{abstract}

Keywords: Calcium, phosphorus, vitamin D3, bone quality and mineral retention.

\section{INTRODUCTION}

Plant feed ingredients contain $\mathrm{P}$ which is not completely available for chickens due to its complexity as phytate $\mathrm{P}(\mathrm{PP})$, and using these ingredients in chicken diets results in more excretion of phytate-bound $\mathrm{P}$ (Kornegay et al., 1996). Recent estimates confirmed that the world releases amount of $\mathrm{P}$ that is substantially greater than pre-industrial emissions (Rockstrom et al., 2009). Therefore improvements in freshwater quality and other ecosystems require reductions in $\mathrm{P}$ escape in these systems (Conley et al., 2009). The adaptation of animals to deficient nutrient has been long eminent. In this regard, animals respond to nutrient limitation by increasing absorption and utilization, which in turn, decreases the excretion of restricted nutrient (Yan et al., 2005). Moreover, excess levels of Ca in the diet reduce the utilization of PP in the chicken gut (Applegate et al., 2003). High intakes of vitamin D3 and low intakes of Ca independently increase PP utilization in the low P diets (Mohammed et al., 1991) by increasing the activity of intestinal phytase (Shafey et al., 1991). In addition, availability of PP from plant feed ingredients would be increased either by feeding diets deficient in P or with vitamin D3 supplementation (Onyango et al., 2006) which in turn, reduces the use of costly inorganic $\mathrm{P}$ and minimizes $\mathrm{P}$ excretion (Rama Rao et al., 2006). Decreasing dietary P, to concentrations that do not impair broiler performance, results in decreased litter P (Yan et al., 2001; Yan et al., 2003; Yan et al., 2005). Vitamin D3 has been shown to improve body weight gain, feed efficiency, bone ash, and breast meat yield (McNutt and Haussler, 1973; McNaughton et al., 1977) of broilers. Because of lower cost of synthetic vitamin D3 compared with that of supplemental $\mathrm{P}$, reducing $\mathrm{P}$ and Ca concentrations with high levels of D3 might be beneficial for economic and environmental reasons (Rama Rao et al., 2006). The current study was designed to examine effects of deficiency of Ca and NPP in broiler diets in the presence of extra levels of vitamin D3 and subsequent effects on performance and bone quality. 


\section{MATERIALS AND METHODS}

\section{Birds and Management:}

All procedures used during the study were approved by the University of Ain Shams Animal Care Committee. Two hundred forty unsexed one-day-old Hubbard broiler chicks were randomly distributed into six treatments. Each treatment comprised of 40 chicks divided into four replicates of 10 chicks each. The chicks were reared up to five weeks of age in wire-floored batteries. Each pen was fitted with individual feeder, waterer, and excreta collection tray and housing two birds. Birds were provided ad libitum access to feed and water during the study, with light provided with UV-filtered incandescent bulbs. All chicks were reared under similar managerial and hygienic conditions and were vaccinated by drinking-water-based vaccinations against Newcastle and Gumboro diseases. Chicks were brought from Hatcheries of Cairo Poultry Company Ltd., 10th of Ramadan City, Egypt. Vaccinations from Veterinary Serum and Vaccine Research Institute VSVRI, Cairo, Egypt.

\section{Diets}

Three different starter diets (fed from one to 14 days); Control (C) $1.00 \%$ Ca, $0.50 \%$ NPP supplemented with D3 3,000 IU/kg; Medium (M) $0.75 \%$ Ca, 0.37\% NPP supplemented with D3 5,000 IU/kg and Low (L) $0.50 \% \mathrm{Ca}, 0.25 \%$ NPP supplemented with D3 7,000 IU/kg. Three different grower diets (fed from 15 to 35 days); Control (C) $0.90 \%$ Ca, 0.45\% NPP supplemented with D3 3,000 IU/kg; Medium (M) $0.65 \%$ Ca, 0.32\% NPP supplemented with D3 6,000 IU/kg and Low (L) 0.40\% Ca, 0.20\% NPP supplemented with D3 9,000 IU/kg. Six dietary treatments (Table 1) were distributed according to diets fed to birds consecutively during starter and grower phases as; $(\mathrm{C} / \mathrm{C}) ;(\mathrm{C} / \mathrm{M}) ;(\mathrm{C} / \mathrm{L}) ;(\mathrm{M} / \mathrm{M}) ;(\mathrm{M} / \mathrm{L})$ and $(\mathrm{L} / \mathrm{L})$. Birds of $(\mathrm{C} / \mathrm{C})$ group were considered as control group according to requirements of birds (listed in Hubbard Broiler Management Guide) during starter and grower phases. Diets were formulated ensuring sufficient supply of nutrients to be isocaloric and isonitrogenous according to (NRC, 1994) and were offered in an age-relative mash form. Samples of mixed feeds were retained for analysis of calcium and phosphorus at Poultry Nutrition Laboratory, Faculty of Agriculture, Ain Shams University, Cairo, Egypt.

\section{Chemical and Biochemical Analyses:}

Total excreta were collected two days prior to the end of the experiment to determine $\mathrm{Ca}$ and $\mathrm{P}$ retention, feed consumption during digestive trial period was recorded. Samples of diets, tibia and excreta were analyzed for Ca (AOAC, 1990a) and P (AOAC, 1990b). Each nutrient was analyzed in quadruplicate. Blood sampling was done simultaneously with slaughtering at the end grower and starter, and then blood was immediately centrifuged at 3,000 rpm for 10 minutes to separate plasma. Blood plasma samples were analyzed spectrophotometrically for Ca (Young, 2000), inorganic P (iP) (Tietz, 1995), and alkaline phosphatase (ALP) activity (Young, 1995) using Cromatest diagnostic kits, Linear Chemicals s.l., Joaquim Costa, 18 - 2a planta, 08390 Montgat. Spain.

\section{Parameters Measured:}

Mean body weights of treatment were taken weekly and recorded at 14 and $35 \mathrm{~d}$ of age. Feed consumption was determined at the same ages. Body weight gain (BWG) and feed conversion ratio (FCR; weight gain/feed intake) were calculated for both starter and grower. At $35 \mathrm{~d}$, six birds per treatment were killed, and tibia was removed for ash determination on dry fat-free bones as described by (AOAC, 1990c). Seedor index (SI) values expressing bone mineral density were obtained by dividing tibia dry weight $(\mathrm{g})$ by its length $(\mathrm{cm})$, as proposed by (Seedor et al., 1991). Tibia breaking strength (TBS) was determined on tibiae at wet-basis following the method of (Crenshaw et al., 1981) by applying the simple three-point bending concept at Research Center of Properties and Testing of Materials and Quality Control, Engineering Consulting Center, Faculty of Engineering, Ain Shams University, with an Instron Universal Testing Machine, which was set at a maximum load of $50 \mathrm{Kg}$ and a crosshead speed of $1 \mathrm{~m} /$ $\min$.

\section{Statistical Analysis:}

Data were subjected to one way analysis of variance General Linear Model (GLM) procedure of (SAS, 2003) user's guide according to the following model:

$\mathrm{Yij}=\mu+\mathrm{Ti}+$ eij

Where; $\mu=$ overall mean, $\mathrm{Ti}=$ dietary treatment, eij = experimental error. Individual effects of dietary treatments were compared using Duncan's multiple range tests (Duncan, 1955) at $\alpha$ level equal to 0.05 or 0.01 . 


\section{RESULTS AND DISCUSSION}

\section{Growth performance:}

Overall results of BWG and FCR (Table 2) indicated that supplementations of vitamin D3 have conquered $\mathrm{Ca}$ and $\mathrm{P}$ deficiency. These performance traits represents an obvious effect of high D3 levels $(6,000$ or $9,000 \mathrm{IU} / \mathrm{Kg})$ which make chicks of $(\mathrm{M} / \mathrm{M})$, $(\mathrm{M} / \mathrm{L})$ or $(\mathrm{L} / \mathrm{L})$ treatments to be significantly similar to those of $(\mathrm{C} / \mathrm{C})$ treatment. These results agreed with findings of other studies (Rama Rao et al., 2008) and (Thabet, 2010) which indicated that deficient Ca and NPP diets supplemented with vitamin D3 improved body weight as well as body weight gain. Surplus D3 levels $(6,000$ or 9,000 IU/Kg) have no effect on feed consumption and a positive effect on FCR as recently reported (Thabet, 2010) and (Yan et al., 2005); in regard to these parameters, birds of (M/M), (M/L) or (L/L) treatments showed significantly similar values compared with those of $(\mathrm{C} / \mathrm{C})$ treatment. The fact that $(\mathrm{L} / \mathrm{L})$ group presented productive performance similar to those of $(\mathrm{C} / \mathrm{C})$ could be explained by broilers' ability to adapt to Ca \& NPP deficiency (Yan et al., 2005).

\section{Blood parameters:}

Values of blood plasma Ca, P concentrations and ALP activity are presented in Table (3). Data of starter showed no significant difference between $(\mathrm{C}),(\mathrm{M})$ or $(\mathrm{L})$ treatments for both $\mathrm{Ca}$ and $\mathrm{P}$, while ALP was high with (M) and (L) than (C). During grower, values of $\mathrm{Ca}$ for birds fed lower Ca with higher levels of $\mathrm{D} 3$ as of $(\mathrm{M} / \mathrm{M}),(\mathrm{M} / \mathrm{L})$ or $(\mathrm{L} / \mathrm{L})$ treatments were similar to those of $(\mathrm{C} / \mathrm{C})$ treatment, which in turn is in conformity with the rule of D3 in Ca metabolism. On the other hand, birds of (C/L) treatment showed significantly lower plasma Ca compared with those of $(\mathrm{L} / \mathrm{L})$ treatment which were well adapted to $\mathrm{Ca}$ deficiency and exhibited better $\mathrm{Ca}$ retention. The same trend was observed in plasma $\mathrm{P}$ concentrations. ALP activity values in birds fed deficient $\mathrm{Ca}$ and $\mathrm{P}$ diets were higher than those fed optimal $\mathrm{Ca}$ and $\mathrm{P}$ levels. Higher dietary D3 levels $(9,000 \mathrm{IU} / \mathrm{Kg})$ have seemingly helped birds fed deficient $\mathrm{Ca}$ and $\mathrm{P}$ to uphold this deficiency which finally presented no significant differences between $(\mathrm{L} / \mathrm{L})$ and $(\mathrm{C} / \mathrm{C})$ groups. These results were in agreement with those of other studies (Rama Rao et al., 2006) and (Thabet, 2010) which stated that decreasing dietary Ca and NPP did not affect plasma Ca, P concentration while using diets containing extra levels of vitamin D3. On the other hand, ALP activity for $(\mathrm{M} / \mathrm{M})$ and $(\mathrm{M} / \mathrm{L})$ was significantly higher compared to other treatments, while $\mathrm{P}$ of $(\mathrm{M} / \mathrm{M})$ was lower than that of $(\mathrm{C} / \mathrm{C})$. Increased concentrations of $\mathrm{Ca}$ and iP in serum of broilers fed low $\mathrm{Ca}$ and NPP with extra D3 might suggest beneficial effect of higher D3 on utilization of dietary Ca and NPP (Rama Rao et al., 2006). These results clearly show that diets containing both low levels of $\mathrm{Ca}$ and elevated levels of vitamin D3 permit greater utilization of PP and reduce NPP needs (Mohammed et al., 1991) which was obvious when birds were seemingly adapted to lower levels of Ca and P (Yan et al., 2005).

\section{Bone composition and measurements:}

Data in Table (4) showed no significant effect of dietary treatments on values of toe ash, wet and dry tibia weight, meaning that increasing dietary vitamin D3 $(9,000 \mathrm{IU} / \mathrm{Kg})$ had significantly overcome negative effects of $\mathrm{Ca}$ and $\mathrm{P}$ deficiency on bone composition. In this regard, it was clearly noticed that birds of $(\mathrm{L} / \mathrm{L})$ group gave values notably similar to those of $(\mathrm{C} / \mathrm{C})$ treatment. These results apply for tibia ash and tibia P. In addition, similar tibia Ca values were observed between birds of $(\mathrm{C} / \mathrm{M}),(\mathrm{L} / \mathrm{L})$ or $(\mathrm{C} / \mathrm{C})$ treatments. In the same way, it was observed that addition high levels of D3 (6,000 or 9,000 IU/Kg) imposed a positive effect on tibia length and width indicating no significant differences between birds of $(\mathrm{M} / \mathrm{M}),(\mathrm{M} / \mathrm{L}),(\mathrm{L} / \mathrm{L})$ or $(\mathrm{C} / \mathrm{C})$ treatments at five weeks of age. The same trend was observed in tibia breaking strength when birds fed high levels of D3 at either $(\mathrm{M} / \mathrm{M}),(\mathrm{M} / \mathrm{L})$ or $(\mathrm{L} / \mathrm{L})$ treatments, showed significantly similar values as those of $(\mathrm{C} / \mathrm{C})$ treatment. These results were in harmony with those found by (Edwards et al., 2002) who found that supplemental D3 appeared to prevent incidence of rickets and improves the bone ash contents, and (Baker et al., 1998) who found that bone ash was increased with high D3 concentrations. Large increases in percentage of bone ash suggest large increases in the utilization of $\mathrm{Ca}, \mathrm{P}$, and PP by the chicks receiving very high vitamin D3 levels in the diet (Edwards et al., 2002). These results were also in harmony with those observed by (Thabet, 2010) who indicated that tibia breaking strength was in accordance with tibia ash content and bones were stronger with birds fed in high vitamin D3 diets when compared to those fed control diet.

\section{Mineral retention:}

As anticipated, NPP and Ca consumption were directly related to dietary NPP and Ca levels (Table 5). Mineral retention values shown in Table (6) showed noticeable effect of adding higher D3 levels $(9,000$ $\mathrm{IU} / \mathrm{Kg})$, where birds of $(\mathrm{C} / \mathrm{L}),(\mathrm{M} / \mathrm{L})$ or $(\mathrm{L} / \mathrm{L})$ groups retained relatively more $\mathrm{Ca}$ and $\mathrm{P}$ compared with 


\section{Abdelaziz et al.}

those of $(\mathrm{C} / \mathrm{C})$ treatment. As D3 in high levels $(9,000 \mathrm{IU} / \mathrm{Kg})$ had positively affected Ca retention, the same trend was observed in $\mathrm{P}$ retention but it was less noticeable than that of $\mathrm{Ca}$ which might be related to the fact that D3 improve Ca digestibility in the first place (Scott et al., 1982). These results were in harmony with those found by (Steenbock and Herting, 1955) and (Thabet, 2010) who stated that dietary vitamin D3 has long been known to increase PP digestibility and reduce the rachitogenic nature of low$\mathrm{Ca}$, high phytate diets. Generally, improvement of PP utilization upon large vitamin D3 supplementations (9,000 IU/Kg) might be accredited to increased biosynthesis and/or activity of intestinal phytase (Shafey et al., 1990), increased phytate hydrolysis by stimulation Ca absorption making phytate more sensitive to hydrolysis and utilization (Mohammed et al., 1991) or increased P absorption (Tanaka and Deluca, 1974). Reduced levels of NPP and Ca can improve the utilization of PP probably due to lower pH media brought about by lower $\mathrm{Ca}$ and $\mathrm{P}$ which in turn satisfies growth and activity of phytase-producing bacteria and in the same way, the acidic $\mathrm{pH}$ also encourage better activity for natural phytase found in feedstuffs (Dhandu and Angel, 2003). These effects might also be augmented by the effect of gradual adaptation to deficiency of both Ca and P (Yan et al., 2005). Additionally it was found (Chou et al., 2009), that 25-OH D3 consistently resulted in longer villus length of the duodenum and jejunum in birds which might in part justify better absorption of minerals.

In conclusion, under conditions of this experiment, it is clear that feeding extra levels of vitamin D3 $(6,000$ or $9,000 \mathrm{IU} / \mathrm{Kg})$ present beneficial effects on performance of broilers fed low $\mathrm{Ca}$ and $\mathrm{P}$ diets till the end of growing period.

\section{CONCLUSIONS}

1. Body weight gain, feed conversion, $\mathrm{Ca}$, and iP concentrations in plasma and tibia ash content in broilers fed lower concentrations of $\mathrm{Ca}$ and NPP appeared significantly similar to those fed recommended concentrations of these minerals, when birds were fed extra levels of vitamin D3.

2. Most of bone mineralization features in broilers fed lower concentrations of Ca and NPP with high concentrations of D3 $(6,000$ or $9,000 \mathrm{IU} / \mathrm{kg})$ were similar to those fed the recommended levels of Ca, NPP, and D3.

3. Retention of $\mathrm{Ca}$ and $\mathrm{P}$ increased significantly with increased concentrations of $\mathrm{D} 3$ in diets containing lower concentrations of Ca and NPP, except for (M/M) group.

4. Reducing the concentrations of supplemental NPP from $0.50 \%$ and $0.45 \%$ to $0.25 \%$ and $0.20 \%$; and $\mathrm{Ca}$ from $1.0 \%$ and $0.90 \%$ to $0.50 \%$ and $0.40 \%$ during starter and grower phases, respectively, with higher supplemental concentrations of D3 reduced feed cost by about \$0.05/bird up to $35 \mathrm{~d}$ of age.

5. Based on results achieved, it is concluded that performance and bone mineralization in broilers, except for $(\mathrm{M} / \mathrm{L})$ group, could be normally maintained when feeding suboptimal concentrations of $\mathrm{Ca}$ and NPP with higher level of D3 (9,000 IU/kg).

\section{REFERENCES}

Applegate, T.J.; R. Angel and H.L. Classen (2003). Effect of dietary calcium, 25-hydroxycholecalciferol, or bird strain on small intestinal phytase activity in broiler chickens. Poult Sci., 82:1140-1148.

AOAC (1990a). Association of Official Analytical Chemists. Calcium in feeds. Method 945.03. Official Methods of Analysis. 15th ed., Arlington, VA.

AOAC, (1990b). Association of Official Analytical Chemists. Phosphorus in feeds. Method 957.02. Official Methods of Analysis. 15th ed. Arlington, VA.

AOAC, (1990c). Association of Official Analytical Chemists. Ash in plant materials. Method 941.12. Official Methods of Analysis. 15th ed. Arlington, VA.

Baker, D.H.; R.R. Biehl and J.L. Emmert (1998). Vitamin D3 requirement of young chicks receiving diets varying in calcium and available phosphorus. Br Poult. Sci., 39:413-417.

Chou, S.H.; T.K. Chung and B. Yu (2009). Effects of supplemental 25-hydroxycholecalciferol on growth performance, small intestinal morphology, and immune response of broiler chickens. Poult Sci., 88:2333-2341.

Conley, D.J.; H.W. Paerl; R.W. Howarth; D.F. Boesch; S.P. Seitzinger; K.E. Havens; C. Lancelot; G.E. Likens (2009). Controlling Eutrophication: Nitrogen and Phosphorus. Science, 323:1014-1015.

Crenshaw, T.D.; E.R. Peo, Jr.; A.J. Lewis and B.D. Moser (1981). Bone strength as a trait for assessing mineralization in swine: A critical review of techniques involved. J Anim. Sci., 53:827-835. 
Dhandu, A.S. and R. Angel (2003). Broiler nonphytin phosphorus requirement in the finisher and withdrawal phases of a commercial four-phase feeding system. Poult. Sci., 82:1257-1265.

Duncan, D.B. (1955). Multiple range and Multiple F tests. Biometrics, 11:1-42.

Edwards, H.M., Jr. (2002). Studies on the efficacy of cholecalciferol and derivatives for stimulating phytate utilization in broilers. Poult. Sci., 81:1026-1031.

Kornegay, E.T.; D.M. Denbow; Z. Yi and V. Ravindran (1996). Response of broilers to graded levels of microbial phytase added to maize-soyabean-meal-based diets containing three levels of non-phytate phosphorus. Br J Nutr., 75:839-852.

McNaughton, J.L.; E.J. Day and B.C. Dilworth (1977). The chick's requirement for 25hydroxycholecalciferol and cholecalciferol. Poult. Sci., 56:511-516.

McNutt, K.W. and M.R. Haussler (1973). Nutritional effectiveness of 1, 25-dihydroxycholecalciferol in preventing rickets in chicks. J Nutr 103:681-689.

Mohammed, A.; M.J. Gibney and T.G. Taylor (1991). The effects of dietary levels of inorganic phosphorus, calcium and cholecalciferol on the digestibility of phytate-P by the chick. Br. J. Nutr., 66:251-259.

National Research Council (1994). Nutrient Requirements of Poultry. 9th Rev. ed. National Academy Press, Washington, DC.

Onyango, E.M.; E.K. Asem and O. Adeola (2006). Dietary cholecalciferol and phosphorus influence intestinal mucosa phytase activity in broiler chicks. Br. Poult Sci., 47:632-639.

Rama Rao, S.V.; M.V.L.N. Raju; A.K. Panda; G.S. Sunder and R.P. Sharma (2006). Effect of high concentrations of cholecalciferol on growth, bone mineralization, and mineral retention in broiler chicks fed suboptimal concentrations of calcium and nonphytate phosphorus. J. Appl. Poult. Res., 15:493-501.

Rama Rao, S.V.; M.V.L.N. Raju; A.K. Panda; P.N. Saharai; M.R. Reddy; G.S. Sunder and R.P. Sharma (2008). Effect of surfeit concentrations of vitamin D3 on performance, bone mineralization and mineral retention in commercial broiler chicks. J. Poult. Sci., 42:25-30.

Rockstrom, J.; W. Steffen; K. Noone; A. Persson; F.S. Chapin, 3rd; E.F. Lambin; T.M. Lenton; M. Scheffer; C. Folke; H.J. Schellnhuber; B. Nykvist; C.A. de Wit; T. Hughes; S. van der Leeuw; H. Rodhe; S. Sorlin; P.K. Snyder; R. Costanza; U. Svedin; M. Falkenmark; L. Karlberg; R.W. Corell; V.J. Fabry; J. Hansen; B. Walker; D. Liverman; K. Richardson; P. Crutzen and J.A. Foley (2009). A safe operating space for humanity. Nature, 461:472-475.

SAS Institute (2003). SAS System for Microsoft Windows. Version 9.1. SAS Institute. Inc., Cary, NC.

Scott, M.L.; M.C. Nesheim and R.J. Young (1982). Nutrition of the chicken. 3rd ed. M.L. Scott, Ithaca, N.Y.

Seedor, J.G.; H.A. Quartuccio and D.D. Thompson (1991). The bisphosphonate alendronate (MK-217) inhibits bone loss due to ovariectomy in rats. J Bone Miner Res, 6:339-346.

Shafey, T.M.; M.W. McDonald and R.A. Pym (1990). Effects of dietary calcium, available phosphorus and vitamin $\mathrm{D}$ on growth rate, food utilisation, plasma and bone constituents and calcium and phosphorus retention of commercial broiler strains. Br. Poult. Sci., 31:587-602.

Shafey, T.M.; M.W. McDonald and J.G. Dingle (1991). Effects of dietary calcium and available phosphorus concentration on digesta $\mathrm{pH}$ and on the availability of calcium, iron, magnesium and zinc from the intestinal contents of meat chickens. Br. Poult. Sci., 32:185-194.

Steenbock, H. and D.C. Herting (1955). Vitamin D and growth. J Nutr 57:449-468.

Tanaka, Y. and H.F. Deluca (1974). Role of 1, 25-dihydroxyvitamin D3 in maintaining serum phosphorus and curing rickets. Proc Natl Acad Sci USA, 71:1040-1044.

Thabet, H.A. (2010). Effect of high concentration of cholecalciferol in deficient calcium and phosphorus broiler diets on productive performance and carcass quality. Ph.D., Ain Shams Univ., Cairo, Egypt.

Tietz, N.W. (1995). Clinical guide to laboratory tests. 3rd ed. W. B. Saunders Co, Philadelphia, PA.

Yan, F.; J.H. Kersey and P.W. Waldroup (2001). Phosphorus requirements of broiler chicks three to six weeks of age as influenced by phytase supplementation. Poult. Sci., 80:455-459.

Yan, F.; J.H. Kersey; C.A. Fritts and P.W. Waldroup (2003). Phosphorus requirements of broiler chicks six to nine weeks of age as influenced by phytase supplementation. Poult. Sci., 82:294-300.

Yan, F.; R. Angel; C. Ashwell; A. Mitchell and M. Christman (2005). Evaluation of the broiler's ability to adapt to an early moderate deficiency of phosphorus and calcium. Poult. Sci., 84:1232-1241.

Young, D.S. (1995). Effects of drugs on clinical laboratory tests. 4th ed. American Association for Clinical Chemistry Press, Washington, DC.

Young, D. S. (2000). Effects of drugs on clinical laboratory tests. 5th ed. American Association for Clinical Chemistry Press, Washington, DC. 
Table (1). Feed ingredients and chemical composition of experimental diets.

\begin{tabular}{|c|c|c|c|c|c|c|}
\hline \multirow{2}{*}{$\begin{array}{ll}\text { Ingredients } & \\
& \text { Starter }\end{array}$} & \multicolumn{6}{|c|}{ Dietary Treatments } \\
\hline & \multicolumn{3}{|c|}{ Control (C) } & \multicolumn{2}{|c|}{ Medium (M) } & Low $(\mathrm{L})$ \\
\hline Yellow Corn & \multicolumn{3}{|c|}{56.01} & \multicolumn{2}{|c|}{57.75} & 59.49 \\
\hline SBM $44 \%$ & \multicolumn{3}{|c|}{28.83} & \multicolumn{2}{|c|}{28.85} & 28.84 \\
\hline Corn Gluten $60 \%$ & \multicolumn{3}{|c|}{8.97} & \multicolumn{2}{|c|}{8.71} & 8.48 \\
\hline Soybean Oil & \multicolumn{3}{|c|}{1.50} & \multicolumn{2}{|c|}{1.00} & 0.50 \\
\hline $\mathrm{Ca}$ Carbonate $\left(\mathrm{CaCO}_{3}\right)$ & \multicolumn{3}{|c|}{1.60} & \multicolumn{2}{|c|}{1.22} & 0.80 \\
\hline $\mathrm{MCP}$ & \multicolumn{3}{|c|}{1.85} & \multicolumn{2}{|c|}{1.23} & 0.65 \\
\hline HCI-LYS & \multicolumn{3}{|c|}{0.39} & \multicolumn{2}{|c|}{0.39} & 0.39 \\
\hline METH (MHA) & \multicolumn{3}{|c|}{0.25} & \multicolumn{2}{|c|}{0.25} & 0.25 \\
\hline Salt $(\mathrm{NaCl})$ & \multicolumn{3}{|c|}{0.30} & \multicolumn{2}{|c|}{0.30} & 0.30 \\
\hline Premix $^{1}$ & \multicolumn{3}{|c|}{0.30} & \multicolumn{2}{|c|}{0.30} & 0.30 \\
\hline Total & \multicolumn{3}{|c|}{100} & \multicolumn{2}{|c|}{100} & 100 \\
\hline Chemical Composition (Cal & & & & & & \\
\hline $\mathrm{CP} \%$ & & 23.00 & & & & 23.00 \\
\hline $\mathrm{ME} \mathrm{Kcal/Kg}$ & & 3,000 & & & & 3,000 \\
\hline $\mathrm{Ca} \%$ & & 1.000 & & & & 0.500 \\
\hline $\mathrm{NPP} \%$ & & 0.500 & & & & 0.250 \\
\hline Vitamin $\mathrm{D}_{3} \mathrm{IU} / \mathrm{Kg}^{2}$ & & 3,000 & & & & 7,000 \\
\hline Price (L.E.)/ Ton & & 3292 & & & & 3179 \\
\hline Grower & $\mathrm{C} / \mathrm{C}$ & $\mathrm{C} / \mathrm{M}$ & $\mathrm{C} / \mathrm{L}$ & $\mathrm{M} / \mathrm{M}$ & $\mathrm{M} / \mathrm{L}$ & $\mathrm{L} / \mathrm{L}$ \\
\hline Yellow Corn & 59.90 & 61.66 & 63.39 & 61.66 & 63.39 & 63.39 \\
\hline SBM $44 \%$ & 26.39 & 26.45 & 26.40 & 26.45 & 26.40 & 26.40 \\
\hline Corn Gluten $60 \%$ & 6.94 & 6.66 & 6.46 & 6.66 & 6.46 & 6.46 \\
\hline Soybean Oil & 2.50 & 2.00 & 1.50 & 2.00 & 1.50 & 1.50 \\
\hline $\mathrm{Ca}$ Carbonate $\left(\mathrm{CaCO}_{3}\right)$ & 1.46 & 1.05 & 0.64 & 1.05 & 0.64 & 0.64 \\
\hline $\mathrm{MCP}$ & 1.64 & 1.02 & 0.45 & 1.02 & 0.45 & 0.45 \\
\hline HCl-LYS & 0.32 & 0.31 & 0.31 & 0.31 & 0.31 & 0.31 \\
\hline METH (MHA) & 0.25 & 0.25 & 0.25 & 0.25 & 0.25 & 0.25 \\
\hline Salt $(\mathrm{NaCl})$ & 0.30 & 0.30 & 0.30 & 0.30 & 0.30 & 0.30 \\
\hline Premix $^{1}$ & 0.30 & 0.30 & 0.30 & 0.30 & 0.30 & 0.30 \\
\hline Total & 100 & 100 & 100 & 100 & 100 & 100 \\
\hline Chemical Composition (Cal & & & & & & \\
\hline $\mathrm{CP} \%$ & 21.00 & 21.00 & 21.00 & 21.00 & 21.00 & 21.00 \\
\hline $\mathrm{ME} \mathrm{Kcal/Kg}$ & 3100 & 3100 & 3100 & 3100 & 3100 & 3100 \\
\hline $\mathrm{Ca} \%$ & 0.900 & 0.650 & 0.400 & 0.650 & 0.400 & 0.400 \\
\hline $\mathrm{NPP} \%$ & 0.450 & 0.325 & 0.200 & 0.325 & 0.200 & 0.200 \\
\hline Vitamin $\mathrm{D}_{3} \mathrm{IU} / \mathrm{Kg}^{2}$ & 3,000 & 6,000 & 9,000 & 6,000 & 9,000 & 9,000 \\
\hline Price (L.E.)/ Ton & 3163 & 3107 & 3059 & 3107 & 3059 & 3059 \\
\hline
\end{tabular}


Table (2). Effect of different dietary treatments on productive performance during different experimental periods.

\begin{tabular}{|c|c|c|c|c|c|c|c|}
\hline \multirow{2}{*}{ Items } & \multicolumn{6}{|c|}{ Dietary Treatments } & \multirow[b]{2}{*}{ Sig } \\
\hline & $\mathrm{C} / \mathrm{C}$ & $\mathrm{C} / \mathrm{M}$ & $\mathrm{C} / \mathrm{L}$ & $\mathrm{M} / \mathrm{M}$ & $\mathrm{M} / \mathrm{L}$ & $\mathrm{L} / \mathrm{L}$ & \\
\hline \multicolumn{8}{|c|}{ Live body weight (g) } \\
\hline 14 days & & $388.42 \pm 3.97$ & & $379.55 \pm 5.50$ & & $378.25 \pm 9.77$ & NS \\
\hline 35 days & $1900.70^{\mathrm{ab}} \pm 49.24$ & $1939.25^{\mathrm{a}} \pm 26.18$ & $1791.30^{\mathrm{b}} \pm 20.45$ & $1819.80^{\mathrm{ab}} \pm 38.76$ & $1830.43^{\mathrm{ab}} \pm 44.57$ & $1856.28^{\mathrm{ab}} \pm 46.98$ & $*$ \\
\hline \multicolumn{8}{|c|}{ Daily weight gain $(\mathrm{g})$} \\
\hline $0-14$ days & & $24.37 \pm 0.29$ & & $23.70 \pm 0.39$ & & $23.57 \pm 0.72$ & NS \\
\hline $15-35$ days & $71.74^{\mathrm{ab}} \pm 2.08$ & $75.05^{\mathrm{a}} \pm 1.22$ & $67.00^{\mathrm{b}} \pm 0.89$ & $68.91^{\mathrm{b}} \pm 1.77$ & $68.75^{\mathrm{b}} \pm 1.71$ & $70.38^{\mathrm{ab}} \pm 1.84$ & $*$ \\
\hline $0-35$ days & $52.95^{\mathrm{ab}} \pm 1.40$ & $54.06^{\mathrm{a}} \pm 0.75$ & $49.82^{\mathrm{b}} \pm 0.58$ & $50.62^{\mathrm{ab}} \pm 1.09$ & $50.93^{\mathrm{ab}} \pm 1.26$ & $51.66^{\mathrm{ab}} \pm 1.34$ & $*$ \\
\hline \multicolumn{8}{|c|}{ Daily feed consumption $(\mathrm{g})$} \\
\hline $0-14$ days & & $32.33 \pm 0.32$ & & $31.79 \pm 0.48$ & & $32.13 \pm 0.55$ & NS \\
\hline $15-35$ days & $118.03^{\mathrm{ab}} \pm 2.81$ & $122.73^{\mathrm{a}} \pm 2.38$ & $114.17^{\mathrm{b}} \pm 2.18$ & $113.24^{\mathrm{b}} \pm 1.66$ & $114.28^{\mathrm{b}} \pm 3.17$ & $116.10^{\mathrm{ab}} \pm 1.96$ & $*$ \\
\hline $0-35$ days & $83.93^{\mathrm{ab}} \pm 1.86$ & $86.47^{\mathrm{a}} \pm 1.66$ & $81.36^{\mathrm{ab}} \pm 1.45$ & $80.43^{\mathrm{b}} \pm 1.08$ & $81.52^{\mathrm{ab}} \pm 2.20$ & $82.51^{\mathrm{ab}} \pm 1.31$ & $*$ \\
\hline \multicolumn{8}{|c|}{ Feed conversion ratio (g feed/g gain) } \\
\hline $0-14$ days & & $1.32 \pm 0.01$ & & $1.33 \pm 0.01$ & & $1.36 \pm 0.01$ & NS \\
\hline $15-35$ days & $1.64^{\mathrm{b}} \pm 0.01$ & $1.63^{\mathrm{b}} \pm 0.01$ & $1.70^{\mathrm{a}} \pm 0.01$ & $1.64^{\mathrm{b}} \pm 0.02$ & $1.66^{\mathrm{ab}} \pm 0.01$ & $1.65^{\mathrm{b}} \pm 0.01$ & $*$ \\
\hline $0-35$ days & $1.58^{\mathrm{b}} \pm 0.01$ & $1.58^{\mathrm{b}} \pm 0.01$ & $1.63^{\mathrm{a}} \pm 0.01$ & $1.59^{\mathrm{ab}} \pm 0.02$ & $1.60^{\mathrm{ab}} \pm 0.01$ & $1.59^{\mathrm{ab}} \pm 0.01$ & $*$ \\
\hline
\end{tabular}

$a, b$ Means within the same row with different superscripts are significantly different. Sig. $=$ Significance $* *(P \leq 0.01), *(P \leq 0.05)$. NS $=$ Non-Significant .

Table (3). Effect of different dietary treatments on plasma Ca, P and ALP of broiler chicks at 14 and 35 days of age.

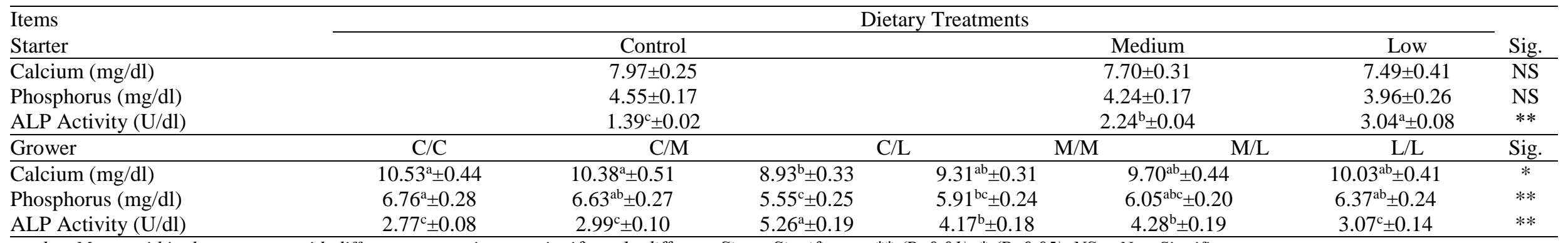

$a, b, c$ Means within the same row with different superscripts are significantly different. Sig. $=$ Significance $* *(P \leq 0.01), *(P \leq 0.05)$. NS $=$ Non-Significant. 
Abdelaziz et al.

Table (4). Effect of different dietary treatments on some aspects of bone composition and measurements at 35 days of age.

\begin{tabular}{|c|c|c|c|c|c|c|c|}
\hline \multirow{2}{*}{ Items } & \multicolumn{7}{|c|}{ Dietary Treatments } \\
\hline & $\mathrm{C} / \mathrm{C}$ & $\mathrm{C} / \mathrm{M}$ & $\mathrm{C} / \mathrm{L}$ & $\mathrm{M} / \mathrm{M}$ & $\mathrm{M} / \mathrm{L}$ & $\mathrm{L} / \mathrm{L}$ & Sig. \\
\hline Toe Ash \% & $11.34 \pm 0.61$ & $11.31 \pm 0.24$ & $10.24 \pm 0.37$ & $11.16 \pm 0.22$ & $10.75 \pm 0.38$ & $11.21 \pm 0.42$ & NS \\
\hline Wet Tibia Weight $\%$ & $0.54 \pm 0.01$ & $0.55 \pm 0.01$ & $0.53 \pm 0.02$ & $0.53 \pm 0.01$ & $0.55 \pm 0.01$ & $0.55 \pm 0.02$ & NS \\
\hline Dry Tibia Weight $\%$ & $0.26 \pm 0.01$ & $0.26 \pm 0.01$ & $0.24 \pm 0.01$ & $0.25 \pm 0.01$ & $0.26 \pm 0.01$ & $0.25 \pm 0.01$ & NS \\
\hline Tibia Ash \% & $42.04^{\mathrm{a}} \pm 0.50$ & $41.29^{\mathrm{a}} \pm 0.36$ & $38.32^{\mathrm{b}} \pm 0.52$ & $40.54^{\mathrm{ab}} \pm 0.66$ & $39.24^{\mathrm{ab}} \pm 1.08$ & $41.00^{\mathrm{ab}} \pm 1.61$ & $*$ \\
\hline Tibia Ca \% & $13.65^{\mathrm{a}} \pm 0.19$ & $13.51^{\mathrm{a}} \pm 0.11$ & $11.48^{c} \pm 0.16$ & $12.32^{b c} \pm 0.23$ & $12.10^{c} \pm 0.41$ & $13.13^{\mathrm{ab}} \pm 0.16$ & $* *$ \\
\hline Tibia P \% & $7.79^{\mathrm{a}} \pm 0.90$ & $7.63^{\mathrm{ab}} \pm 0.08$ & $7.07^{\mathrm{b}} \pm 0.11$ & $7.51^{\mathrm{ab}} \pm 0.18$ & $7.27^{\mathrm{ab}} \pm 0.25$ & $7.58^{\mathrm{ab}} \pm 0.11$ & $*$ \\
\hline Tibia Length (mm) & $90.11^{\mathrm{ab}} \pm 0.85$ & $92.35^{\mathrm{a}} \pm 0.46$ & $88.88^{\mathrm{b}} \pm 0.85$ & $90.66^{\mathrm{ab}} \pm 0.73$ & $92.28^{\mathrm{a}} \pm 0.83$ & $91.93^{\mathrm{a}} \pm 1.02$ & $*$ \\
\hline Tibia Width (mm) & $7.30^{\mathrm{ab}} \pm 0.15$ & $7.35^{\mathrm{ab}} \pm 0.17$ & $6.96^{\mathrm{b}} \pm 0.17$ & $7.08^{\mathrm{ab}} \pm 0.26$ & $7.28^{\mathrm{ab}} \pm 0.13$ & $7.69^{a} \pm 0.29$ & $*$ \\
\hline Tibia Breaking Strength $\left(\mathrm{Kg} / \mathrm{cm}^{2}\right)$ & $20.10^{\mathrm{a}} \pm 0.44$ & $19.56^{\mathrm{a}} \pm 0.41$ & $13.06^{c} \pm 0.79$ & $18.36^{\mathrm{ab}} \pm 0.76$ & $17.53^{\mathrm{b}} \pm 0.79$ & $18.16^{\mathrm{ab}} \pm 0.30$ & $* *$ \\
\hline
\end{tabular}

Table (5). Effect of different dietary treatments on Ca, NPP and vitamin D3 intake during different experimental phases.

\begin{tabular}{|c|c|c|c|c|c|c|c|}
\hline \multirow{2}{*}{$\begin{array}{ll} & \text { Items } \\
\text { Starter (0-14 days) } & \\
\end{array}$} & \multicolumn{7}{|c|}{ Dietary Treatments } \\
\hline & \multicolumn{3}{|c|}{ Control } & \multicolumn{2}{|c|}{ Medium } & Low & Sig. \\
\hline Ca intake $(\mathrm{g})$ & \multicolumn{3}{|c|}{$4.52^{\mathrm{a}} \pm 0.04$} & \multicolumn{2}{|c|}{$3.33^{\mathrm{b}} \pm 0.05$} & $2.25^{\mathrm{c}} \pm 0.04$ & $* *$ \\
\hline NPP intake (g) & \multicolumn{3}{|c|}{$2.26^{\mathrm{a}} \pm 0.02$} & \multicolumn{2}{|c|}{$1.67^{\mathrm{b}} \pm 0.02$} & $1.12^{\mathrm{c}} \pm 0.01$ & $* *$ \\
\hline $\mathrm{D}_{3}$ intake $(\mathrm{IU})$ & \multicolumn{3}{|c|}{$\begin{array}{c}1358.17^{\mathrm{c}} \\
\pm 13.83\end{array}$} & \multicolumn{2}{|c|}{$2226.00^{\mathrm{b}}$} & $\begin{array}{c}3149.50^{\mathrm{a}} \\
\pm 54.55\end{array}$ & $* *$ \\
\hline Grower (15-35 days) & $\mathrm{C} / \mathrm{C}$ & $\mathrm{C} / \mathrm{M}$ & $\mathrm{C} / \mathrm{L}$ & $\mathrm{M} / \mathrm{M}$ & $\mathrm{M} / \mathrm{L}$ & $\mathrm{L} / \mathrm{L}$ & Sig. \\
\hline Ca intake $(\mathrm{g})$ & $22.31^{\mathrm{a}} \pm 0.53$ & $16.10^{\mathrm{b}} \pm 0.31$ & $9.59^{\mathrm{d}} \pm 0.18$ & $14.86^{c} \pm 0.21$ & $9.60^{\mathrm{d}} \pm 0.26$ & $9.75^{\mathrm{d}} \pm 0.16$ & $* *$ \\
\hline NPP intake (g) & $11.15^{\mathrm{a}} \pm 0.26$ & $8.38^{\mathrm{b}} \pm 0.16$ & $4.79^{\mathrm{d}} \pm 0.09$ & $7.73^{\mathrm{c}} \pm 0.11$ & $4.80^{\mathrm{d}} \pm 0.13$ & $4.87^{\mathrm{d}} \pm 0.08$ & $* *$ \\
\hline $\mathrm{D}_{3}$ intake (IU) & $\begin{array}{l}7436.00^{\mathrm{d}} \\
\pm 177.04\end{array}$ & $\begin{array}{c}15464.50^{\mathrm{b}} \\
\pm 299.78\end{array}$ & $\begin{array}{c}21579.25^{\mathrm{a}} \\
\pm 413.63\end{array}$ & $\begin{array}{c}14268.25^{\mathrm{c}} \\
\pm 209.73\end{array}$ & $\begin{array}{c}21600.00^{\mathrm{a}} \\
\pm 599.49\end{array}$ & $\begin{array}{c}21943.00^{\mathrm{a}} \\
\pm 370.57\end{array}$ & $* *$ \\
\hline Overall (0-35 days) & $\mathrm{C} / \mathrm{C}$ & $\mathrm{C} / \mathrm{M}$ & $\mathrm{C} / \mathrm{L}$ & $\mathrm{M} / \mathrm{M}$ & $\mathrm{M} / \mathrm{L}$ & $\mathrm{L} / \mathrm{L}$ & Sig. \\
\hline Ca intake (g) & $26.89^{\mathrm{a}} \pm 0.59$ & $20.60^{\mathrm{b}} \pm 0.39$ & $14.09^{\mathrm{d}} \pm 0.23$ & $18.14^{\mathrm{c}} \pm 0.24$ & $13.00^{\mathrm{e}} \pm 0.34$ & $12.00^{\mathrm{e}} \pm 0.19$ & $* *$ \\
\hline NPP intake (g) & $13.45^{\mathrm{a}} \pm 0.29$ & $10.62^{\mathrm{b}} \pm 0.20$ & $7.04^{\mathrm{d}} \pm 0.11$ & $9.36^{\mathrm{c}} \pm 0.12$ & $6.50^{\mathrm{e}} \pm 0.17$ & $6.00^{\mathrm{e}} \pm 0.09$ & $* *$ \\
\hline $\mathrm{D}_{3}$ intake (IU) & $\begin{array}{l}8812.75^{\mathrm{d}} \\
\pm 195.81 \\
\end{array}$ & $\begin{array}{c}16811.75^{\mathrm{c}} \\
\pm 323.74 \\
\end{array}$ & $\begin{array}{c}22929.50^{\mathrm{b}} \\
\pm 428.19 \\
\end{array}$ & $\begin{array}{c}16453.75^{\mathrm{c}} \\
\pm 225.19 \\
\end{array}$ & $\begin{array}{c}23866.50^{\mathrm{b}} \\
\pm 651.94 \\
\end{array}$ & $\begin{array}{c}25092.25^{\mathrm{a}} \\
\pm 404.39 \\
\end{array}$ & $* *$ \\
\hline
\end{tabular}


Egyptian J. Nutrition and Feeds (2015)

Table (6). Effect of different dietary treatments on calcium and phosphorus retention at 35 days of age.

\begin{tabular}{|c|c|c|c|c|c|c|c|}
\hline \multirow[t]{2}{*}{ Items } & \multicolumn{7}{|c|}{ Dietary Treatments } \\
\hline & $\mathrm{C} / \mathrm{C}$ & $\mathrm{C} / \mathrm{M}$ & $\mathrm{C} / \mathrm{L}$ & $\mathrm{M} / \mathrm{M}$ & $\mathrm{M} / \mathrm{L}$ & $\mathrm{L} / \mathrm{L}$ & $\underline{\text { Sig. }}$. \\
\hline & \multicolumn{7}{|c|}{ Calcium } \\
\hline Intake $(\mathrm{g})$ & $3.35^{\mathrm{a}} \pm 0.16$ & $2.49^{\mathrm{b}} \pm 0.18$ & $1.56^{\mathrm{c}} \pm 0.16$ & $2.37^{\mathrm{b}} \pm 0.14$ & $1.57^{\mathrm{c}} \pm 0.06$ & $1.65^{\mathrm{c}} \pm 0.05$ & $* *$ \\
\hline Excretion (g) & $1.92^{\mathrm{a}} \pm 0.12$ & $1.28^{\mathrm{b}} \pm 0.12$ & $0.73^{\mathrm{c}} \pm 0.07$ & $1.19^{\mathrm{b}} \pm 0.16$ & $0.70^{c} \pm 0.04$ & $0.72^{c} \pm 0.06$ & $* *$ \\
\hline Retention (g) & $1.43^{\mathrm{a}} \pm 0.13$ & $1.21^{\mathrm{a}} \pm 0.07$ & $0.83^{\mathrm{b}} \pm 0.09$ & $1.18^{\mathrm{a}} \pm 0.06$ & $0.87^{\mathrm{b}} \pm 0.04$ & $0.93^{\mathrm{b}} \pm 0.04$ & $* *$ \\
\hline Retention $\%$ & $42.69^{\mathrm{b}} \pm 2.97$ & $48.59^{\mathrm{ab}} \pm 1.35$ & $53.21^{\mathrm{a}} \pm 0.86$ & $49.79^{\mathrm{ab}} \pm 4.69$ & $55.41^{\mathrm{a}} \pm 2.18$ & $56.36^{\mathrm{a}} \pm 2.86$ & $*$ \\
\hline \multirow[t]{2}{*}{ Relative Retention } & $100.00 \%$ & $113.82 \%$ & $124.64 \%$ & $116.63 \%$ & $129.80 \%$ & $132.02 \%$ & - \\
\hline & \multicolumn{7}{|c|}{ Phosphorus } \\
\hline Intake (g) & $2.55^{\mathrm{a}} \pm 0.12$ & $2.14^{\mathrm{b}} \pm 0.16$ & $1.78^{\mathrm{b}} \pm 0.18$ & $2.04^{\mathrm{b}} \pm 0.12$ & $1.79^{\mathrm{b}} \pm 0.07$ & $1.87^{\mathrm{b}} \pm 0.06$ & $* *$ \\
\hline Excretion (g) & $0.98^{\mathrm{a}} \pm 0.05$ & $0.79^{\mathrm{ab}} \pm 0.08$ & $0.61^{\mathrm{b}} \pm 0.04$ & $0.74^{\mathrm{b}} \pm 0.06$ & $0.59^{\mathrm{b}} \pm 0.06$ & $0.57^{\mathrm{b}} \pm 0.09$ & $* *$ \\
\hline Retention (g) & $1.57^{\mathrm{a}} \pm 0.07$ & $1.35^{\mathrm{ab}} \pm 0.10$ & $1.17^{b} \pm 0.14$ & $1.30^{\mathrm{ab}} \pm 0.08$ & $1.20^{\mathrm{b}} \pm 0.09$ & $1.30^{\mathrm{ab}} \pm 0.07$ & $*$ \\
\hline Retention $\%$ & $61.57^{\mathrm{b}} \pm 0.80$ & $63.08^{\mathrm{ab}} \pm 2.20$ & $65.73^{\mathrm{a}} \pm 1.16$ & $63.73^{\mathrm{ab}} \pm 2.51$ & $67.04^{\mathrm{a}} \pm 3.68$ & $69.52^{\mathrm{a}} \pm 4.22$ & * \\
\hline Relative Retention & $100.00 \%$ & $102.45 \%$ & $106.76 \%$ & $103.51 \%$ & $108.88 \%$ & $112.91 \%$ & - \\
\hline
\end{tabular}

$a, b, c$ Means within the same row with different superscripts are significantly different. Sig. $=$ Significance $* *(P \leq 0.01), *(P \leq 0.05)$. NS $=$ Non Significant. 


\section{فيتامين دس يعالج تأثير نقص الكالسيوم والفوسفور على دجاج التسمين}

\section{مروان عبد العزيز محمود عبد العزيز، نبيل محمد المدنى ،علاء الدين عبد السلام حميد و حسين عبد الله العلايلى}

قسم إنتاج اللاواجن ـ كلية الززراعة ـ جامعة عين شعس - الثاهرة- مصر.

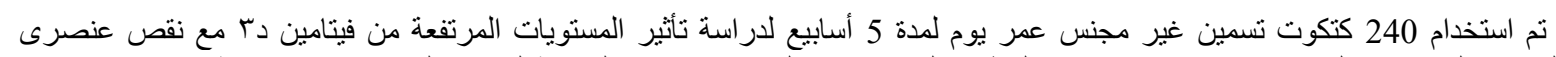

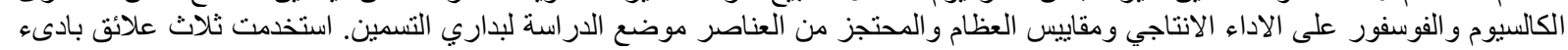

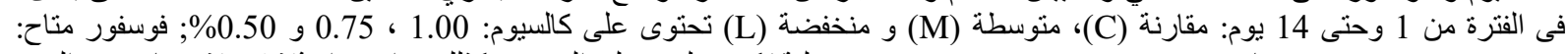

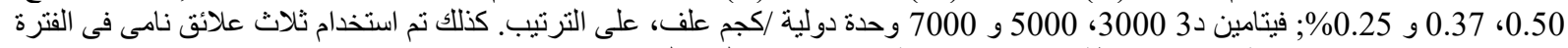

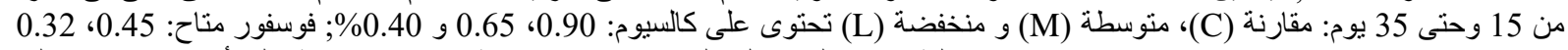

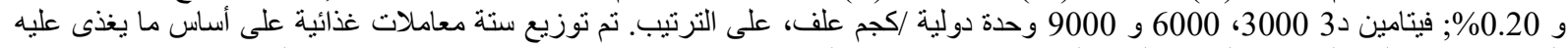

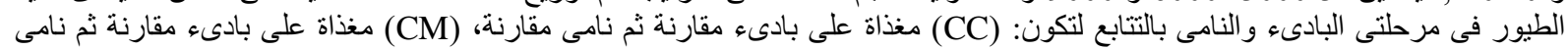

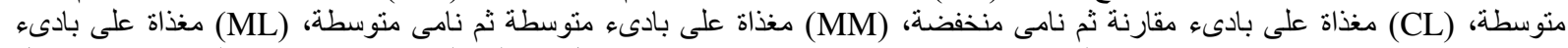

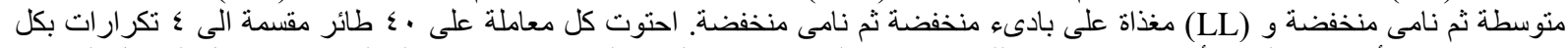

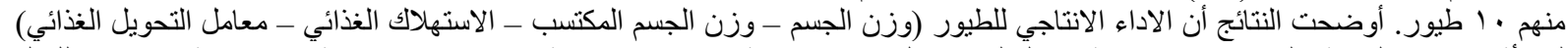

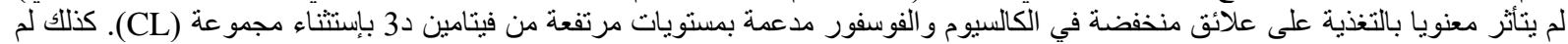

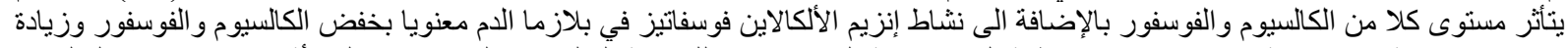

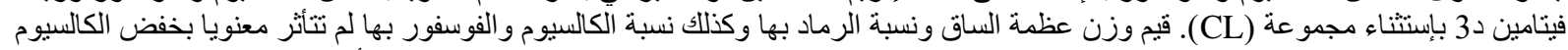

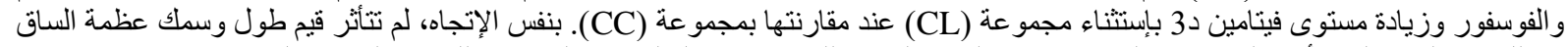

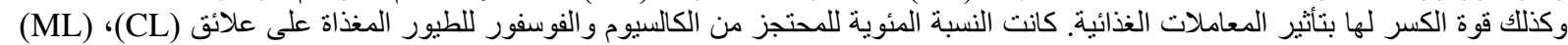

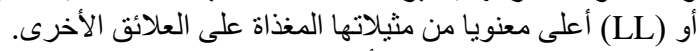

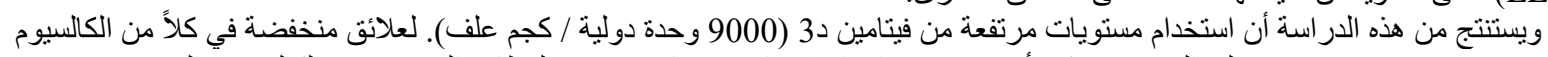

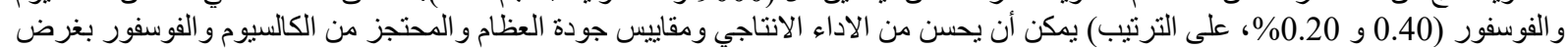
تقليل التلوث البيئى وبخاصة من عنصر الفوسفور بالاضافة الى تقليل تكلفة الغذاء. 